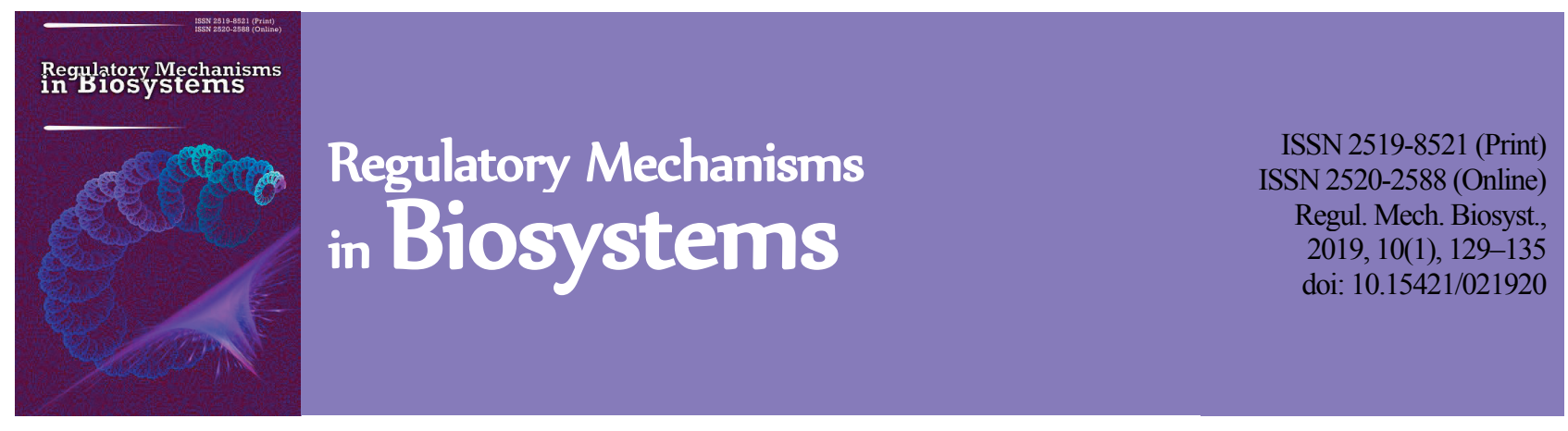

\title{
Morphological features of atrial myocardium embryonic development and its changes caused by hypoxia effect
}

\author{
K. M. Shevchenko
}

\author{
State Institution "Dnipropetrovsk Medical Academy of the Ministry of Health of Ukraine", Dnipro, Ukraine
}

Article info

Received 17.02.2019

Received in revised form 16.03.2019

Accepted 18.03.2019

State Institution "Dnipropetrovsk Medical Academy of the Ministry of Health of Ukraine",

Vernadskyst., 9,

Dnipro, 49044, Ukraine.

Tel.: +38-095-326-01-68.

E-mail:

katerynabaker@gmail.com

\begin{abstract}
Shevchenko, K. M. (2019). Morphological features of atrial myocardium embryonic development and its changes caused by hypoxia effect. Regulatory Mechanisms in Biosystems, 10(1), 129-135. doi:10.15421/021920
\end{abstract}

Mortality and morbidity during the prenatal period of development remain a real problem at the present time. The Scientific Committee EURO-PERISTAT has revealed that mortality of fetuses associated with congenital abnormalities is on average 15$20 \%$ across Europe. Hypoxia is one of the top causes of death of fetuses. Since the heart begins to function before birth, influence of teratogenic factors leads to formation of anomalies of its development. Congenital heart defects are the most common of these and occur with a frequency of $24 \%$. Abnormalities associated with the atrium occur with frequency of 6.4 per 10,000 cases. Investigation of structural changes of the atrial myocardium is a key for understanding of pathogenic mechanisms of cardiovascular diseases that are caused by influence of hypoxia. Nowadays, a great deal of research is being dedicated to normal cardiogenesis and much less work is focused on abnormal heart development. There are numerous teratogenic factors such as alcohol, retinoic acid, hyperthermia, hypoxia that are most common causes of heart diseases. The attention of researchers has been predominantly focused on study of changes of the ventricular myocardium under the effect of hypoxia. It is known that the atrium is different from the ventricles by derivation, development and structure. Therefore, the effects of pathological factors on the atrial myocardium will be different as complared to their effect on the ventricles. Also, almost all research has focused on study of consequences of hypoxia at the late stages of cardiogenesis. However, the greatest number of abnormalities is associated with the early embryonic period, as structures that continue development are more sensitive to the effects of harmful factors. Thus, comparative analysis of scientific research devoted to morphological study of atrial myocardium transformations on the cellular and ultrastructural levels under the influence of hypoxia during the stages of cardiogenesis is an important task.

Keywords: cardiogenesis; atria; ultrastructure of cardiomyocytes; rats.

\section{Introduction}

Consequences of prenatal hypoxia influence take first place among the causes of fetal mortality (Nichols et al., 2012). Hypoxia inhibits intrauterine growth and results in low birth weight and premature infant mortality (Patterson \& Zhang, 2010). Low oxygen content is the main factor that adversely affects cardiogenesis (Giussani et al., 2012). 0.2-4.0\% of all pregnancies in developed industrial countries are complicated by cardiovascular diseases (Regitz-Zagrosek et al., 2011). Additionally, effects of prenatal hypoxia lead to formation of heart defects and cardiomyopathies in adults (Giussani et al., 2014; Rooket al., 2014; Mozaffarian et al., 2015).

In contrast to adults, development of fetuses is accompanied by influence of hypoxia. Fetal hearts due to their high ability of adaptation develop in low oxygen tension for a long time (Breckenridge et al., 2013). Moreover, physiological hypoxia is a required condition of cardiogenesis. It is well known that hypoxia inducible factor 1 (HIF-1) and vascular endothelial growth factor (VEGF) play a crucial role in the formation of coronary vessels of the myocardium (Patterson \& Zhang, 2010). However, pathological hypoxia influence (level of oxygen pressure is $8-12 \%$ in the mother's blood) damages the structure of the myocardium and increases the risk of cardiovascular disease as a consequence (Altimiras \& Phu, 2000; Marei, 2002; Sugishitaa et al., 2004). Modified expression of cardioprotective genes increases the vulnerability to the development of ischemia and reperfusion injury syndrome in the future (Bruneau, 2003; Schell et al., 2005; Zhang, 2005; Wilhide et al., 2011). Nowadays, cardiovascular diseases take first place among causes of death in adults
(Smith et al., 2012; Mozaffarian et al., 2015). Consequently, the influence of hypoxia on cardiogenesis is a highly relevant issue, which is confirmed by the constantly high percentage of articles in scientific databases (Medline, PubMed). However, despite the large number of works, many issues remain unclear.

\section{Atrial myocardium development during early stages of cardiogenesis}

At the early stages of cardiogenesis (up to 8 weeks of human development) major morphological changes are associated with formation of the chambers and septum of the heart (Goodlett, 2011). Numerous harmful factors, in particular hypoxia, have a negative effect on organ formation (McCutcheon et al., 1982), resulting in abnormal structure (Elmstedt et al., 2013). A wide range of birth defects, the formation of which occurs in the early stages of cardiogenesis is evidence of the vulnerability of the embryonic heart during this period. This necessitates the use of a significant arsenal of research methods: light microscopy (Ream et al., 2008), immunohistochemistry (Garlanda et al., 1997; Azar et al., 2003; Dong \& Thompson, 2006; Tonne et al., 2011), electron microscopy (Schaper et al., 1985; McKenzie et al., 1994; Zhang \& Pasumarthi, 2007; Oxford et al., 2011; Cury et al., 2012), microcomputer tomography (Nieman \& Turnbull, 2010; Gilbert et al., 2012), ultrasound microscopy (Araujo Júnior et al., 2012; Hernandez-Andrade et al., 2012; Hongmei et al., 2012; Gindes et al., 2012), echocardiography (Choi et al., 2013; Lee \&Won, 2013), confocal microscopy (Sands et al., 2005), and three-dimensional visualization (Momoi et al., 2012). Each method has 
its advantages and disadvantages. During embryonic development, significant spatial and temporal morphogenetic changes of embryonic hearts occur. Therefore, visualization of these volumetric and dynamic changes and their assessment in a two-dimensional mode is impossible. Ultrasound methods give an opportunity for the study of three-dimensional structures but, because of the small size of the biological objects, use of these methods for investigation of cardiogenesis in the early stages is impossible (Gu et al., 2012).

The method of episcopal microscopy (Matsui et al., 2010) allows one to obtain high-quality three-dimensional images of an organ but it does not allow morphometric study of surface-volume characteristics. In recent years, the method of computer modelling has become increasingly relevant (Schleich et al., 2005; Clerico et al., 2011; Tobón et al., 2013). Morphological reconstruction of the heart allows one to visualize relief of the surface and also makes possible assessment of dimensional characteristics of the object, such as volume of the chambers' surface area (Fig. 1).

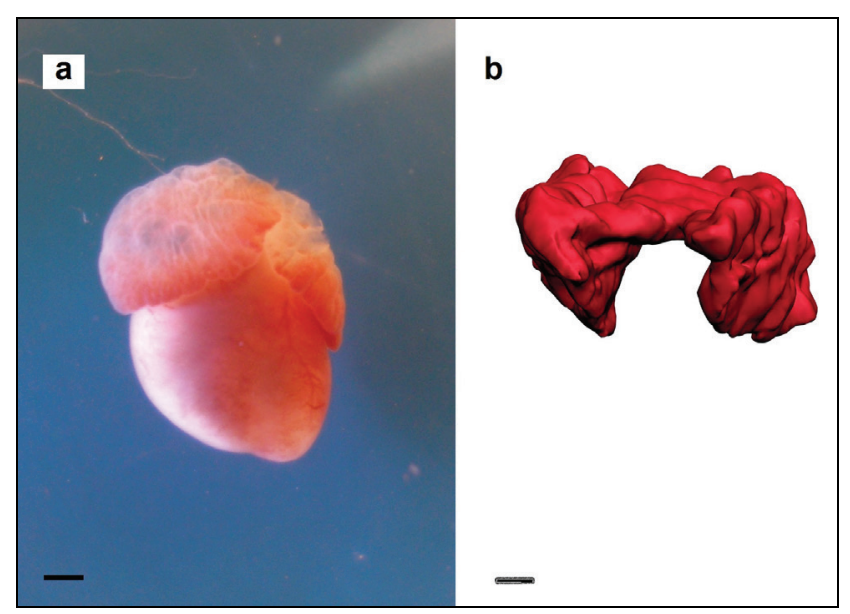

Fig. 1. Representative image of the rat embryo heart at ED18 (a) and 3D model of the rat embryo atria at $\mathrm{ED} 18$ (top view) (b): scale bars $=1 \mathrm{~mm}$

The first major event in cardiogenesis is formation of a primitive heart tube at the 9th embryonic day (ED) of rats' development (IX stage of human development by Carnegie). Heart precursor cells of the visceral mesoderm differentiate into myocardial cells and after emigration form a heart tube (Patterson \& Zhang, 2010). According to the histological analysis, the heart tube consists of two layers of cells: the inner layer of cells forms the endocardium and cavity of the heart tube, the outer layer gives rise to myocardium (Lockhart et al., 2011). There is cardiogel between these the two layers. According to previous studies (Ream et al., 2008) fetuses that were exposed to hypoxia at the this stage were not viable. Alterations of development in the early stages lead to pathologies that are incompatible with life (Ruckman et al., 1985). Thus, research at this stage is not feasible.

The next important event of cardiogenesis is looping. As a result, the heart gets its S-shape which is ventrally convex and dorsally concave (Männer, 2000). At the ED10 of rats' development (XI-XII stages of human development in Carnegie) the common atrium communicates with a primitive ventricle via a common embryonic duct (atrioventricular canal) (Lamers \& Moorman, 2002). At the caudal end of the heart tube a paired venous sinus is embedded in the mesenchyma of the transverse partition and is separated from the general atrium by a sinoatrial groove. An atrium at this stage is composed of myocardium, which is lined by the epicardium. Both layers are separated by cardiogel (Klotz et al., 2014).

\section{Proliferation of cardiomyocytes and hypoxia affect this process}

An ED10 of rats is characterized by intense changes of myocardium which manifests in rapid proliferation of cardiomyocytes and differenttiation of myofibrils and mitochondria (Kozlov et al., 1995). There is a great number of scientific articles that describe dynamics of the proliferative activity of cardiomyocytes during the stages of cardiogenesis under normal conditions (Shponka, 1994). Recent research is focused on effects of harmful factors, such as hypoxia and hyperthermia, on the processes of myocardial cell proliferation, which underlie heart disease development (Ream et al., 2008). The research field was dedicated to the effect of hypoxia on the proliferative processes of mature mammalian cardiomyocytes (Jopling et al., 2012) and human endothelial cells (Antonova et al., 2012). In an experiment on rats, scientists found out that HIF initiates DNA synthesis and stimulates division of cardiomyocytes (Patterson \& Zhang, 2010). However, it is known that mature cardiomyocytes lose their ability to proliferate. Thus, compensatory mechanisms of mature and embryonic cells will be different (Saiki et al., 1997). In addition, the question about which cell cycle phase is affected by hypoxia remains unclear. Therefore, the reason for the increased number of dividing cells as rapid passage of mitotic phases or activation of DNA-synthetic activity of nuclei is unknown.

The greatest number of abnormalities is associated with the early embryonic period, as developing countries are significantly more sensitive to the actions of various agents (Chan \& Burggren, 2005; Shatorna et al., 2010). However, previous researches dedicated to the effect of intrauterine hypoxia on myocardium are contradictory and fragmentary. Some researchers revealed an increase of proliferative activity of myocardial cells under hypoxia conditions (Shatorna et al., 2010). According to other authors, the effect of intrauterine hypoxia inhibits proliferation of cardiomyocytes (Ream et al., 2008; Xue et al., 2011; Tong et al., 2013). Most likely, these differences are the result of different experimental conditions (modes of hypoxia) or different stages of investigations or different experimental animals (Shatorna et al., 2010). In addition, researchers' attention was mainly focused on cardimyocytes of ventricles. It is well known that cardimyocytes of atria and ventricles are different by intensity of proliferation. In the early stages, proliferative activity of the cardimyocytes of ventricles rapidly increases (Tomanek \& Zheng, 2002), which is evidenced by the significant ventricular thickening of the ventricles compared with the atria. Thus, the question of the effect of prenatal hypoxia on the atrial myocardium during ontogenesis remains unexplored and requires further investigations.

\section{Myofibrillogenesis}

Differentiation of cardiomycytes during stages of embryogenesis is based on changes of myofibrils (Tverdokhlib, 2007). As soon as precursor cells from the primary and secondary cardiac fields enter the way of differentiation, the contraction process begins (Price et al., 1996; Kobayashi et al., 2011), despite the fact that ultrastructure of contractile elements of these cells is different in mature myocytes (Porteret al., 2011). $\alpha$-smooth muscle actin ( $\alpha$-SMA) is a protein that is normally determined at the beginning of the differentiation of the myofibrils of cardiomyocytes and further is gradually replaced by more mature isoforms: $\alpha$-SKA ( $\alpha$-skeletal) and $\alpha$-CAA ( $\alpha$-cardiac) (Clément et al., 2007). In mouse embryos, this substitution is completed by the time of birth. However, in some pathological conditions (hypertrophy) re-expression of embryonic genes is activated, resulting in emergence of earlier isoforms of actin in the postnatal developmental stage. The immunohistochemical method with application of specific antibodies (Jopling et al., 2012) in an experiment on fish revealed that hypoxia leads to more active proliferation and differentiation of mature cardiomyocytes. This manifested in reduction in the intensity of $\alpha$-SMA expression. However, it is known (Patterson \& Zhang, 2010) that embryonic cardiomyocytes are different from mature cardiomyocytes by morphology and by ability to proliferate and by differentiation of myofibrils. Therefore their response to the effect of hypoxia will be also different. Consequently, this issue has escaped the attention of researchers and requires further research.

\section{Septation}

ED11 of rats corresponds to the XIII-XIV stages of human development by Carnegie and is characterized by beginning of cardiac septation. The heart loses its tubular features due to the expanding atrial and ventricular segments. The epicardium covers the heart cavities (Klotz et al., 2014). Epicardial cells separate and migrate into the subepicardial 
space, where they undergo epithelium-mesenchymal transformation and transform into smooth myocytes and fibroblasts (Muñoz-Chápuli et al., 2002; Lie-Venema et al., 2005). Migrant cells release the proliferation factor, which stimulates the division of the cells of the compact myocardium of ventricles (Bhattacharya et al., 2006; Lemley et al., 2006; Ream et al., 2008; Samsa et al., 2013). Alteration of the epicardium leads to formation of congenital anomalies in the development of blood vessels (Tomanek et al., 1996) and cardiomyopathy (non-compact myocardium, arrhythmias, etc.) (Schotten et al., 2011; Pires-Gomes \& Pérez-Pomares, 2013; Zhang et al., 2013).

At ED12 of rats' development (the XV stage of human development by Carnegie), the primitive atria is positioned cephalodorsally (Christoffels et al., 2000). The sinus venosus occupied a dorso-inferior position toward the primitive atria (Tobón et al., 2013). Thus, the posterior part of the mature right atria is basically a venous sinus, embedded into the atria. The embryonic right atria and left atria are represented as auricles in the mature heart. The distal part of the heart tube on the upper wall of the general atria forms a crest which is called the primary septum (Gittenberger-de Groot et al., 2005). The lower part of the primary septum forms a concave arch toward the atrioventricular canal. Subsequently, the endocardial pillows merge, separating the atrioventricular canal into the right and left portions and the primary septum closes. Immediately before this closure, the secondary foramen begins to form. The seconddary foramen on the posterior part of the primary septum is necessary for supporting blood flow through the left atria. At the same time secondary septum also begins to be formed along the anterior roof to the right of the primary septum and to the left of the left venous valve in the interseptal valvular space. The lower part of this septum is also an arch with a dorsal and ventral limb extending to the opening of the lower vena cava. The left venous valve and the false septum merge with this septum. The arch never closes but forms a limb of an oval foramen. In the prenatal period, blood displaces the primary septum to the left and flows through the secondary foramen to the left atria. In the postnatal period, blood pressure in the left atria increases and presses the primary septum to the left, effectively covering the defect (Sadler, 2014). Under normal conditions, the oval foramen closes later but the alteration of this process leads to the formation of a defect of the interatrial septum (Shatorna et al., 2010).

\section{Vasculogenesis}

ED13 of rats (XVI stage of human development by Carnegie) is characterized by the beginning of vasculogenesis in the ventricles (Tomanek et al., 1999). Bloody islets or primary hemocapillars appear in the epicardium. They consist of a layer of endothelial cells and are filled with erythrocytes (Hutchins et al., 1988). Primary hemocapillars become visible near the top of the heart in the interventricular sulcus. Later they are found in the atrioventricular sulcus and in other areas of the ventricles (Bogers et al., 1989). Later, immigration of angioblasts from the epicardium in the myocardium and their differentiation take place. At ED16 coronary vessels appear in the ventricular myocardium (Ratajska et al., 2003). At ED17 hemocapillaries spreading,in the ventricles merge together and form the primary capillary plexus. At the same time, there are no vessels in the atria (Saito, 1998). Consequently, there are numerous scientific atricles devoted to angiogenesis in the ventricles but only little research focused on study of the blood vessels' development in the atrial myocardium.

\section{Stroma development}

The development of the circulatory bed is closely related to the development of the stromal elements (Mashtalir \& Tverdokhlib, 2007). At the early stages of cardiogenesis, fibroblasts have no estimably synthetic activity. Therefore, located between cardiomyocytes and hemocapillaries, they separate them (Tverdokhlib, 2007).

It is known that hypoxia stimulates growth, proliferation and synthetic activity of fibroblasts (Yu, 2003), which results in intensification of collagen formation in the myocardium (Zadnipryanyj \& Tretyakova, 2011). However, there is no information regarding comparative characteristics of the connective tissue components in the atria and ventricles. Since the precursors of the connective tissue cells are the epicardium derivative cells, which in turn stimulate the proliferation of the myocardium cells, the intensity of the proliferation of cardiomyocytes during the cell migration phase may correlate with the number of fibroblasts. It is known that the process of cell migration from the subepicardium initiates proliferation of cardiomyocytes and ventricular myocardium compactification (Tomanek, 2002). Atrial myocardium is less thick as compared to ventricles. This fact reveals that there is a much smaller number of epicardium derivative cells in the atria and thereafter, connective tissue. That is why the atrial myocardium will demonstrate distinctive mechanisms in response to the effect of hypoxia compared with the ventricular myocardium. Most researchers have paid attention to this issue in the ventricles (Tong et al., 2011; Zadnipryanyj \& Tretyakova, 2011) although development of connective tissue of the atria has not been explored.

\section{Trabeculation}

From ED14 of rats (XVI-XVII stages human development by Carnegie) imitation of cardiomyocytes towards the endocardial endothelium take place. This leads to a reduction in the number of cardiogel and the formation of muscle trabeculae (Fig. 2), which are cardiomyocytes lined by endocardial layer (Kozlov et al., 1995). Trabeculae increase cardiac output and provide nutrition and oxygen uptake by the embryonic myocardium before establishment of coronary vascularization without increasing of the heart size (Samsa et al., 2013). The process of trabeculation at the molecular level is controlled by several genes and metabolites (neuregulin, Notch, angiopoietin 1, BMP, endothelin, retinoic acid, etc.) and further modeled under the influence of hemodynamic conditions (Goenezen et al., 2012). However, research regarding the effect of pathological factors (in particular hypoxia) on the process of atria trabeculation is fragmentary and controversial. Some authors assert that influence of hypoxia leads to insufficient development of trabeculae, which leads to premature death of embryos or causes cardiomyopathy in adults (Zhang et al., 2013). However, other researchers (Shatorna et al., 2010) found out that hypoxia conditions increased thickness of trabeculae; however it was not accompanied by an increase in the trabecular layer of the ventricular myocardium. This issue needs further research.

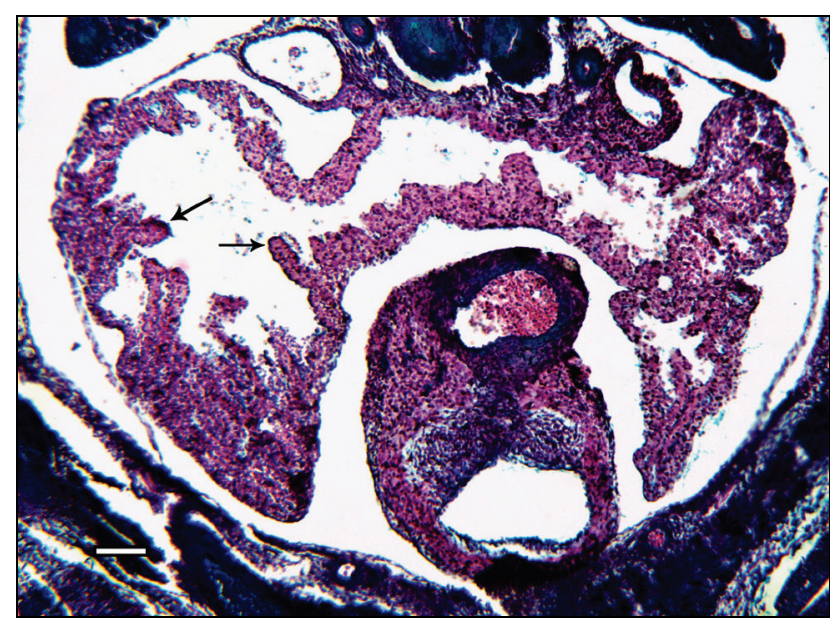

Fig. 2. Representative image of transverse sections of the heart of a rat embryo at ED16: black arrows indicate trabeculae inside the atria chamber; hematoxylin and eosin staining; scale bar $=50 \mu \mathrm{m}$

\section{Secretory apparatus and its development} in the stages of cardiogenesis

At ED14 intensification of secretory activity of cardiomyocytes takes place. Cytoplasm of secretory cardiomyocytes is full of numerous ribosomal granules (Fig. 3), which are mainly grouped in the polysomes (McKenzie et al., 1994). Ribosomes are characterized by electron-dense content, which reflects their high synthetic activity. A significant area of the cell cytoplasm is taken up with granular endoplasmic reticulum (ER). 
The Golgi complex is located near the nucleus. It is known (Knaapen et al., 1997) that free ribosomes and polysosomes are responsible for synthesis of myofibrillar proteins while the Golgi complex and granular ER provide protein synthesis for export. Therefore, the change in the relative volumes of these organelles in the cell is a specific marker of changes in secretory activity of cardiomyocytes (Korostyshevskaya et al., 2013). A considerable amount of research is devoted to the study of ultrastructural changes in secretory cardiomyocytes in experiments with arterial hypertension on rats' embryos (Korostyshevskaya \& Maksimov, 2013) and mature animals (Rahcheeva \& Bugrova, 2010). However, results on effects of hypoxia on secretory apparatus are controversial.

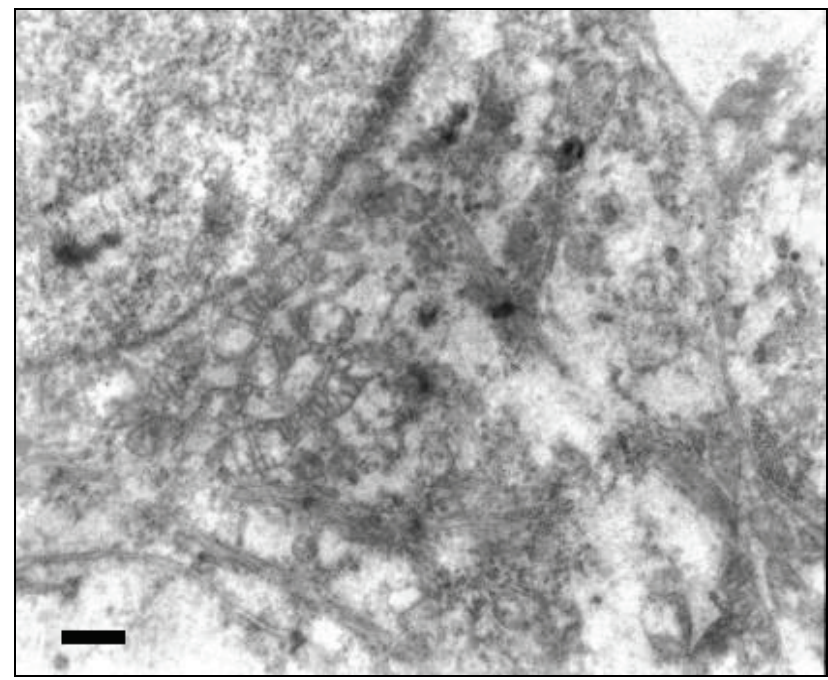

Fig. 3. Representative image of secretory atrial cardiomyocyte at ED14: numerous ribosomes are distributed on the cytoplasm; electron micrograph; scale bar $=500 \mathrm{~nm}$

At ED16 (XIX stage of human development by Carnegie) the secretory apparatus plays an important role since the heart includes various structural elements such as contractile, vascular, metabolic and secretory (Tverdokhlib, 2007). The first research on secretory activity was conducted in 1981 by Adolf de Bold and his colleagues (de Bold, 2011). They injected an extract of the atrial heart tissue of rats into the peripheral blood of rats and observed a rise of diuresis accompanied by a decrease of blood pressure. Based on these results, they concluded that the extract contains the factor that caused these effects and named it as the atrial natriuretic factor (ANF). From 1983 to 1984 many researchers studied the biochemical composition of this factor. As a result, it was established that ANF has a protein nature, thus, it was called atrial natriuretic peptide (ANP) (Gama et al., 2007; Clerico et al., 2011). Later, scientists found that ANP is a hormone, which according to its diuretic and vasodilatation effects is an antagonist of the renin-angiotensinaldosterone system (Casserly et al., 2010; Kuhn, 2012).

At the beginning of electron microscopy era it was found that natriuretic peptides in all mammals are synthesized in atrial cardiomyocytes and accumulated in specific secretory granules (Takei et al., 2011). Immunohistochemical methods revealed that the right auriculum has the most dense accumulation of secretory granules. Distribution of granules gradually decreases in the following sequence: left ventricle, right atria, left atria, interventricular septum (Shevchenko \& Tverdokhlib, 2012). Normally, cardiomyosytes of ventricles are characterized by secretory activity only during ebryonic development. However, under pathological conditions in adults, secretory granules are found in the atria, auricles and additionally in ventricles (Yunge et al., 1980; McKenzie et al., 1994; Sergeeva et al., 2014).

The ultrastructural analysis showed that the secretory cardiomyocytes are characterized by a centrally located nucleus, myofibrils are fused to periphery, mitochondria, Golgi complexes and secretory granules surrooud the nucleus (Rahcheeva \& Bugrova, 2010). Secretory granules appear in the cytoplasm of the secretory cardiomyocytes at ED16 of rats (Silkina, 2005). According to the ultrastructural characteristics, secretory granules are bodies spherical in shape, which contain an electron-dense homogeneous core and are surrounded from the outside by a membrane with a thin light perimembranous rim. These granules are classified as type I granules or granules that still forming. The relative volume of the Golgi complex and granular ER are significantly lower than in the previous period (Knaapen et al., 1997). Correlation between relative volumes of organelles that are responsible for secretory activity indicates stages of the synthetic process. Predomination of the Golgi complex is a marker of synthetic activity, whereas content of secretory granules is the balance of synthesis and isolation (Korostyshevskaya et al., 2013). Some pathological conditions change this correlation. In particular, in myoendocrine cells of embryos of rats with hereditary predisposition to arterial hypertension, it was found that relative volume of the Golgi complex was three times greater than volume of secretory granules, whereas in the norm this correlation was 1.5:1.0 (Maksimov et al., 2013). However, there is not information about hypoxia effecton secretory apparatus.

The most numerous ultrastructural changes of secretory apparatus on atrial cardimyocytes happen at ED18. The number of secretory granules increases significantly in the cytoplasm of cells; granules morphologically differ from each other (Fig. 4). According to classification there are three types of secretory granules: forming, mature and those that diffused. Type I includes small granules with high electron density and a homogeneous matrix surrounded by a membrane with a thin light perimembranous rim. The location of these granules is the same in the Golgi area, which matches the process of their formation. Mature granules (type II) are the largest ones; they have an electron-dense matrix surrounded by membrane. Type III granules contain the most electron-transparent matrix; they have no membrane and located far from the Golgi complex. The percentage correlation of different types of granules in the cytoplasm of cells indicates sequential stages of synthesis, accumulation and excretion of peptide (Korostyshevskaya et al., 2013). It is known that type I granules predominate in cytoplasm of the embryos of rats with hypertension, whereas in the norm the most numerous are type II granules (Maksimov et al., 2013). However, it is not known how hypoxia changes the correlation of different types of granules as well as the secretory phases.

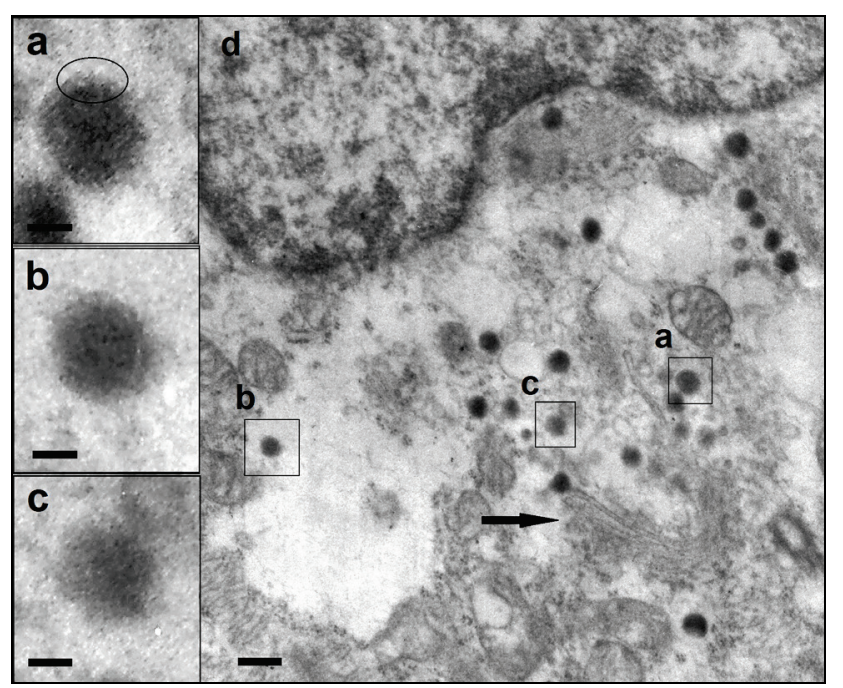

Fig. 4. Representative images of secretory apparatus of rat atrial cardiomyocyte at ED18: cytoplasm contains 3 types of secretory granules; type I granule (a), type II granule (b), type III granule (c); circle surrounds perimembranous rim type of I granule; black arrow indicates Golgi complex near the nucleus; myofibrils are fused to periphery; electron micrograph; scale bars $a, b, c=100 \mathrm{~nm}, d=500 \mathrm{~nm}$

The ontogenetic features of secretory cardiomyocytes' development are indicated in the change of secretory activity. Thus, during embryonic development under normal conditions processes of granules' accumulation predominate. During birth, processes of secretory product release are intensified. In the seven-day-old animals, synthesis processes predominate. In the mature rats, the processes of synthesis, accumulation and release are balanced. This correlation changes under the influence of physiological and pathological factors. It is known that ANP is released 
from the atrial cardiomyocytes to the bloodstream by mechanical stretching of the cavities with excessive volume of the blood pressure (Jacob et al., 2013). In addition, many effects, including hypoxia, stimulate secretion (Casserly et al., 2010). The stimulating effect of hypoxia on the release of ANP is proved (Fujii et al., 2011). It is also known that under the influence of hypoxia, transcription of the ANP increases by activation of HIFs (hypoxia inducible factors) (Patterson \& Zhang, 2010). That means that effects that were investigated under the influence of hypoxia were dependent significantly on the time of its effect on the body (Bugrova et al., 2012). A large number of articles are focused on the physiological aspect of this issue only (Casserly et al., 2010; Arjamaa \& Nikinmaa, 2011).

According to Casserly et al. (2010), the level of ANP increases in both cases: under the influence of acute and chronic hypoxia. Only a small amount of research is aimed at studying the morphological changes of the secretory apparatus under the influence of hypoxia. Thus, investigating the changes in the morphometric indices of the secretory granules in the atria of chicken embryos, the researchers concluded that under the influence of hypoxia in three days there were morphological signs of accelerated release of peptides in the myoendocrine cells. After one week the stimulation of their synthesis took place (Maksimov \& Korostyshevskaya, 2012). However, an increased number of granules may indicate an increase of secretory activity of the cells or occurs due to the problem in the process of the granules' release. Conversely, a reduced number of granules may be the result of low secretory activity or rapid peptide excretion. Since there is so far no clear understanding of the processes of synthesis, accumulation and elimination of ANP at the molecular and biochemical levels, the amount of granules cannot be a specific feature of secretory activity of cells. A more informative criterion for assessing changes in the stages of the synthetic cycle is study of correlation between the organelles responsible for synthesis in the cell (Golgi complex, granular ER) and secretory granules, as well as correlation between different types of secretory granules.

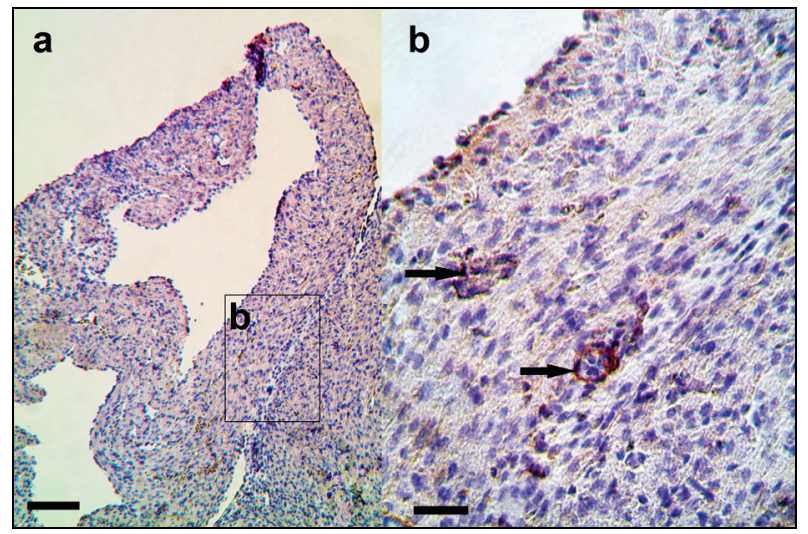

Fig. 5. Representative images of transverse sections of the heart wall of a newborn rat: immunohistochemical reaction, marker $\alpha$-SMA, Mayer's hematoxylin staining; black arrow indicates blood vessel of the atrial myocardium; scale bar $a=25 \mu \mathrm{m}, b=100 \mu \mathrm{m}$

The hearts of newborn rats are characterized by the most significant changes, which are caused by changes in hemodynamic conditions (Tverdokhlib, 2007). This leads to intense growth of cardiomyocytes in the first days after birth. During an experiment with intrauterine hypoxia after birth, renovation of the oxygen supply takes place as well as adaptation of the organism to new conditions of existence. Therefore, the main focus of the researchers was to find out how long changes that happened during the action of the harmful factor will persist after its cessation. In the experiment with mice it was demonstrated that simulation of chronic hypoxia in the period from ED11.5 to ED13.5 (which is ED13-15 of rats' embryos) leads to the ventricular myocardial thinning (Ream et al., 2008), which is the result of dilation. However, other researchers (Shatorna et al., 2010) had found that the effect of hypoxia on ED9 causes hypertrophy of the myocardium of rats and underlies the formation of heart defects. These differences are the result of different modes of hypoxia, different research objects and different experimental conditions. This issue requires further study.
On days 1-2 after the rats' birth, differentiation of arterioles and venules (Fig. 5) takes place. This manifested in development of vascular plexus in the ventricular myocardium, although in the atria these process occurs later (Gössl et al., 2004).

Starting from the 4 day after birth, coronary arteries form collaterals on the atrial myocardium. Other researchers state (Silkina, 2010) that primary hemocapillaries were observed in the atrial myocardium of rats at ED16. It is known that coronary vessels appear in response to increase in nutritional needs caused by increasing myocardial thickness during cardiogenesis (Ratajska et al., 2003). Atrial myocardium thickness is less compared to that of ventricles. Therefore, it is likely that vessels appear in the atria much later than in the ventricles. According to previous studies, it is known that hypoxia stimulates vasculogenesis in the compact ventricular layer (Shatorna et al., 2010), since hypoxia is a trigger for angioblast invasion of the embryo heart (Patterson \& Zhang, 2010).

\section{Conclusions}

This article represents analysis of morphological studies dedicated to embryonic development of the atrial myocardium of rats in normal conditions and under the effect of harmful factors, in particular hypoxia. Despite numerous research in this field, we consider that a great number of the findings are fragmentary and controversial. Some scientists focused on structural changes of the ventricles separately from the atria. The fact that the atria are responsible for construction of the heart wall as well as the ventricles and additionally provide endocrine function makes this an important object for investigation. There are many studies that are focused on normal cardiogenesis. Nowadays, numerous teratogenic factors affect this process and lead to abnormalities and congenital heart diseases. Hypoxia has a leading position among these factors. Most researchers were focused on the physiological aspect of this issue. However, investigation of pathological changes that are the result of hypoxia may be helpful in practical medicine for prevention and treatment of numerous heart diseases.

\section{References}

Altimiras, J., \& Phu, L. (2000). Lack of physiological plasticity in the early chicken embryo exposed to acute hypoxia. The Journal of Experimental Zoology, 286(5), 450-456.

Antonova, L. V., Matveeva, V. G., \& Ponasenko, A. V. (2012). Izmenenie proliferativnoj aktivnosti i zhiznesposobnosti endotelial'nyh kletok cheloveka $\mathrm{v}$ uslovijah gipoksii i posledujushhej re-oksigenacii [Changes of proliferative activity and viability of human endothelial cells under hypoxia and further reoxygenation]. Fundamentalnye Issledovanija, 7, 273-277 (in Russian).

Araujo Júnior, E., Rolo, L. C., Rocha, L. A., Machado Nardozz, L. M., \& Moron, A. F. (2014). The value of $3 \mathrm{D}$ and $4 \mathrm{D}$ assessments of the fetal heart. International Journal of Women's Health, 6, 501-507.

Arjamaa, O., \& Nikinmaa, M. (2011). Hypoxia regulates the natriuretic peptide system. International Journal of Physiology, Pathophysiology and Pharmacology, 3(3), 191-201.

Azar, N., Nasser, M., Sabban, M. E., Bitar, H., Obeid, M., Dbaibo, G. S., \& Bitar, F. F. (2003). Cardiac growth patterns in response to chronic hypoxia in a neonatal rat model mimicking cyanotic heart disease. Experimental and Clinical Cardiology, 8(4), 189-194.

Bhattacharya, S., Macdonald, S. T., \& Farthing, C. R. (2006). Molecular mechanisms controlling the coupled development of myocardium and coronary vasculature. Clinical Science, 111, 35-46.

Bogers, A. J., Gittenberger-de Groot, A. C., Poelmann, R. E., Péault, B. M., \& Huysmans, H. A. (1989). Development of the origin of the coronary arteries, a matter of ingrowth or outgrowth. Anatomy and Embryology, 180, 437-441.

Breckenridge, R. A., Piotrowska, I., Ng, K. E., Ragan, T. J., West, J. A., Kotech, S., Towers, N., Bennett, M., Kienesberger, P. C., Smolenski, R. T., Siddall, H. K., Offer, J. L., Mocanu, M. M., Yelon, D. M., Dyck, J. R., Griffin, J. L., Abramov, A. Y., Gould, A. P., \& Mohun, T. J. (2013). Hypoxic regulation of hand 1 controls the fetal-neonatal switch in cardiac metabolism. PLoS Biology, (9), 1-11.

Bruneau, B. G. (2003). The developing heart and congenital heart defects: A make or break situation. Clinical Genetics, 63(4), 252-261.

Bugrova, M. L., Yakovleva, E. I., \& Abrosimov, D. A. (2012). Vzaimosvjaz' intensivnosti sinteza, nakoplenija i sekrecii predserdnogo natrijureticheskogo peptida kardiomiocitov $\mathrm{s}$ urovnem reguljacii serdechnogo ritma $\mathrm{u}$ krys $\mathrm{v}$ uslovijah rannego postper-fuzionnogo perioda [Correlation of intensity of synthesis, accumulation and secretion of atrial natriuretic peptide in cardiomyocyte with level of heart rate regulation in rats during the early postperfusion period]. Biomedicinskie Issledovanija, 3, 26-29 (in Russian). 
Casserly, B., Pietras, L., Schuyler, J., Wang, R., Hill, N. S., \& Klinger, J. R. (2010). Cardiac atria are the primary source of ANP release in hypoxia adapted rats. Life Sciences, 87(11-12), 382-389.

Chan, T., \& Burggren, W. (2005). Hypoxic incubation creates differential morphological effects during specific developmental critical windows in the embryo of the chicken (Gallus gallus). Respiratory, Physiology and Neurobiology, 145(2-3), 251-263.

Christoffels, V. M., Habets, P. E., Franco, D., Campione, M., de Jong, F., Lamers, W. H., Bao, Z. Z., Palmer, S., Biben, C., Harvey, R. P., \& Moorman, A. F. (2000). Chamber formation and morphogenesis in the developing mammalian heart. Developmental Biology, 223(2), 266-278.

Clément, S., Stouffs, M., Bettiol, E., Kampf, S., Krause, K. H., Chaponnier, C., \& Jaconi, M. (2007). Expression and function of alpha-smooth muscle actin during embryonic-stem-cell-derived cardiomyocyte differentiation. Journal of Cell Science, 120, 229-238.

Clerico, A., Giannoni, A., Vittorini, S., \& Passino, C. (2011). Thirty years of the heart as an endocrine organ: Physiological role and clinical utility of cardiac natriuretic hormones. American Journal of Physiology. Heart and Circulatory Physiology, 301(1), 12-20.

Cury, D. P., Dias, F. J., Sosthenes, M. C., Dos Santos Haemmerle, C. A., Ogawa, K., Da Silva, M. C., Mardegan Issa, J. P., Iyomasa, M. M., \& Watanabe, I. S. (2013). Morphometric, quantitative, and three-dimensional analysis of the heart muscle fibers of old rats: Transmission electron microscopy and highresolution scanning electron microscopy methods. Microscopy Research and Technique, 6(2), 184-195

de Bold, A. J. (2011). Thirty years of research on atrial natriuretic factor: Historical background and emerging concepts. Canadian Journal of Physiology and Pharmacology, 89(8), 527-531.

Dong, Y., \& Thompson, L. P. (2006). Differential expression of endothelial nitric oxide synthase in coronary and cardiac tissue in hypoxic fetal guinea pig hearts. Journal of the Society for Gynecologic Investigation, 13(7), 483-490.

Elmstedt, N. N., Johnson, J. J., Lind, B. B., Ferm-Widlund, K. K., Herling, L. L. Westgren, M. M., \& Brodin, L. A.. (2013). Reference values for fetal tissue velocity imaging and a new approach to evaluate fetal myocardial function. Cardiovascular Ultrasound, 16(11), 29.

European Society of Gynecology (ESG), Association for European Paediatric Cardiology (AEPC), German Society for Gender Medicine (DGesGM), Regitz-Zagrosek, V., Blomstrom Lundqvist, C., Borghi, C., Cifkova, R., Ferreira, R., Foidart, J. M., Gibbs, J. S., Gohlke-Baerwolf, C., Gorenek, B., Iung, B., Kirby, M., Maas, A. H., Morais, J., Nihoyannopoulos, P., Pieper, P. G., Presbitero, P., Roos-Hesselink, J. W., Schaufelberger, M., Seeland, U., \& Torracca, L. (2011). ESC Committee for Practice Guidelines. ESC Guidelines on the management of cardiovascular diseases during pregnancy: The task force on the management of cardiovascular diseases during pregnancy of the European Society of Cardiology (ESC). European Heart Journal, 32(24), 3147-3197.

Fujii, Y., Ishino, K., Tomii, T., Kanamitsu, H., Fujita, Y., Mitsui, H., \& Sano, S. (2011). Atrionatriuretic peptide improves left ventricular function after myocardial global ischemia-reperfusion in hypoxic hearts. Artifical Organs, 36(4), 379-386.

Gama, E. F., de Carvalho, C. A., Liberti, E. A., \& de Souza, R. R. (2007). Atrial natriuretic peptide (ANP)-granules in the guinea pig atrial and auricular cardiocytes: An immunocytochemical and ultrastructural morphometric comparative study. Annals of Anatomy, 189, 457-464

Gilbert, S. H., Benoist, D., Benson, A. P., White, E., Tanner, S. F., Holden, A. V. Dobrzynski, H., Bernus, O., \& Radjenovic, A. (2012). Visualization and quantification of whole rat heart laminar structure using high-spatial resolution contrast-enhanced MRI. American Journal of Physiology. Heart and Circulatory Physiology, 302(1), H287-H298.

Gindes, L., Matsui, H., \& Achiron, R. (2012). Comparison of ex-vivo high-resolution episcopic microscopy with in-vivo four-dimensional high-resolution transvaginal sonography of the first-trimester fetal heart. Ultrasound in Obstetrics and Gynecoly, 39(2), 196-202.

Gittenberger-de Groot, A. C., Bartelings, M. M., Deruiter, M. C., \& Poelmann, R. E. (2005). Basics of cardiac development for the understanding of congenital heart malformations. Pediatric Researches, 57(2), 169-176.

Giussani, D. A., Camm, E. J., Niu, Y., Richter, H. G., Blanco C. E., Gottschalk, R., Blake, E. Z., Horder, K. A., Thakor, A. S., Hansell, J. A., Kane, A. D., Wooding, F. B., Cross, C. M., \& Herrera, E. A. (2012). Developmental programming of cardiovascular dysfunction by prenatalhypoxia and oxidative stress. PLoS One, 7(2), 310-317.

Giussani, D. A., Niu, Y., Herrera, E. A., Richter, H. G., Camm, E. J., Thakor, A. S. Kane, A. D., Hansell, J. A., Brain, K. L., Skeffington, K. L., Itani, N., Wooding, F. B., Cross, C. M., \& Allison, B. J. (2014). Heart disease link to fetal hypoxia and oxidative stress. Advances in Experimental Medicine and Biology, 814, 77-87.

Goenezen, S., Rennie, M. Y., Rugonyi, S. N. (2012). Biomechanics of early cardiac development. Biomechanical Modelling Mechanobiology, 11(8), 1187-1204.
Goodlett, T. (2011). The volumetric analysis of cardiac chambers and three-dimensional cardiac reconstruction during chicken embryo cardiogenesis. Morphologia, 5(2), 39-44.

Gössl, M., Zamir, M., \& Ritman, E. L. (2004). Vasa vasorum growth in the coronary arteries of newborn pigs. Anatomy and Embryology, 208(5), 351-357.

Gu Shi, Jenkins, M. W., \& Peterson, L. M. (2012). Optical coherence tomography captures rapid hemodynamic responses to acute hypoxia in the cardiovascular system of early embryos. Developmental Dynamics, 241(3), 534-544.

Hernandez-Andrade, E., Benavides-Serralde, J. A., Cruz-Martinez, R., Welsh, A. \& Mancilla-Ramirez, J. (2012). Evaluation of conventional Doppler fetal cardiac function parameters: E/A ratios, outflow tracts, and myocardial performance index. Fetal Diagnosis and Therapy, 32(1-2), 22-29.

Hongmei, W., Ying, Z., Ailu, C., \& Wei, S. (2012). Novel application of four-dimensional sonography with B-flow imaging and spatiotemporal image correlation in the assessment of fetal congenital heart defects. Echocardiography (Mount Kisco, N.Y.), 29(5), 614-619.

Hutchins, G. M., Kessler-Hanna, A., \& Moore, G. W. (1988). Development of the coronary arteries in the embryonic human heart. Circulation, 77(6), 1250-1257.

Jacob, M. Saller, T., Chappell, D., Rehm, M., Welsch, U, \& Becker, B. F. (2013). Physiological levels of A-, B- and C-type natriuretic peptide shed the endothelial glycocalyx and enhance vascular permeability. Basic Research in Cardiology, 108(3), 347.

Jopling, C., Suñé, G., Faucherre, A., Fabregat, C., \& Izpisua Belmonte, J. C. (2012). Hypoxia induces myocardial regeneration in zebrafish. Circulation, 126, 3017-3027.

Klotz, L., Norman, S., Vieira, J. M., Masters, M., Rohling, M., Dubé, K. N., Bollini, S., Matsuzaki, F., Carr, C. A., \& Riley, P. R. (2014). Cardiac lymphatics are heterogeneous in origin and respond to injury. Nature, 522(7554), 62-67.

Knaapen, M. W., Vrolijk, B. C., \& Wenink, A. C. (1997). Ultrastructural changes of the myocardium in the embryonic rat heart. The Anatomical Record, $248(2), 233-262$

Kobayashi, T., Maeda, S., Ichise, N., Sato, T., Iwase, T., Seki, S., Yamada, Y., \& Tohse, N. (2011). The beginning of the calcium transient in rat embryonic heart. The Journal of Physiological Sciences, 61(2), 141-149.

Korostyshevskaya, I. M., \& Maksimov, V. F. (2013). Vozrastnye osobennosti miojendokrinnyh kletok serdca u krys v norme i pri nasledstvennoj gipertenzii [Age features of myoendocrine heart cells of rats in normal and hereditary hypertension]. Ontogenez, 44(2), 1-13 (in Russian)

Korostyshevskaya, I. M. Maksimov, V. F. \& Kurganov, S. A (2013). Vozmozhnosti ul'trastrukturnoj ocenki sekretornoj aktivnosti predserdnyh kardiomiocitov [Capability of ultrastructural assessment of atrial cardiomyocyte secretory activity]. Citologija, 55(8), 539-547 (in Russian).

Kozlov, V. A., Tverdohleb, I. V., Shponka, I. S., \& Mishalov, V. D. (1995). Morfologiya razvivayushhegosya serdca (struktura, ultrastruktura, metabolizm) [Morphology of the developing heart (structure, ultrastructure, metabolism)]. Dnepropetrovsk (in Russian).

Kuhn, M. (2012). Endothelial actions of atrial and B-type natriuretic peptides. British Journal of Pharmacology, 166(2), 522-531.

Lamers, W. H., \& Moorman, A. F. (2002). Cardiac septation: A late contribution of the embryonic primary myocardium to heart morphogenesis. Circulation Research, 91(2), 93-103.

Lockhart, M., Wirrig, E., \& Phelps, A. (2011). Extracellular matrix and heart development. Birth defects research. Part A, Clinical and Molecular Teratology, 91(6), 535-550.

Maksimov, V. F., \& Korostyshevskaya, I. M. (2012). Morfogenez i reakcija na gipoksiju miojendokrinnyh kletok predserdija u kurinyh jembrionov (Gallus gallus) [Morphogenesis and reaction to hypoxia of myoendocrine cells of atria of chicken embryos (Gallus gallus)]. Zhurnal Evoljucionnoj Biohimii i Fiziologii, 48(5), 502-508 (in Russian).

Maksimov, V. F., Korostyshevskaya, I. M., \& Markel, A. I. (2013). Natryjuretycheskye peptydy serdca y arteryal'naja gypertenzyja: Eksperymental'noe issledovanye [Natriuretic peptides of the heart and arterial hypertension: An experimental study]. Vestnik RAMN, 1, 4-9.

Marei, H. E. (2002). Fine structural and immunohistochemical localization of cardiac hormones (ANP) in ringht atrium and hypothalamus of the white rat. European Journal of Morphology, 40, 37-41.

Mashtalir, M. A., \& Tverdokhlib, I. V. (2007). Normal'nyj ta anomal'nyj kardiogenez: Uchast' pozasercevyh klitynnyh populjacij [Normal and abnormal cardiogenesis: Participation of extracardiac cell populations]. Morphology, 1(1), 84-88 (in Ukrainian).

Matsui, H., Mohun, T., \& Gardiner, H. M. (2009). Three-dimensional reconstruction imaging of the human foetal heart in the first trimester. European Heart Journal, 31(4), 415.

McCutcheon, I. E., Metcalfe, J., Metzenberg, A. B., \& Ettinger, T. (1982). Organ growth in hyperoxic and hypoxic chick embryos. Respiration Physiology, $50(2), 153-163$.

McKenzie, J. C., Kelley, K. B., Merisko-Liversidge, E. M., Kennedy, J., \& Klein, R. M. (1994). Developmental pattern of ventricular atrial natriuretic peptide 
(ANP) expression in chronically hypoxic rats as an indicator of the hypertrophic process. Journal of Molecular and Cellular Cardiology, 26(6), 753-767.

Momoi, N., Tinney, J. P., Keller, B. B., \& Tobita, K. (2012). Maternal hypoxia and caffeine exposure depress fetal cardiovascular function during primary organogenesis. The Journal of Obstetrics and Gynaecology Research, 38(12), $1343-1351$.

Muñoz-Chápuli, R., González-Iriarte, M., Carmona, R., Atencia, G., Macías, D., \& Pérez-Pomares, J. M. (2002). Cellular precursors of the coronary arteries. Texas Heart Institute Journal, 29, 243-249.

Nesbitt, T., Lemley, A., Davis, J., Yost, M. J., Goodwin, R. L., \& Potts, J. D. (2006). Epicardial development in the rat: A new perspective. Microscopy and Microanalysis, 12, 390-398

Nichols, M., Townsend, N., Luengo-Fernandez, R., Leal, J., Graj, A., Scarborough, P. \& Rayner, M. (2012). European cardiovascular disease statistics 2012. European Heart Network, Brussels, European Society of Cardiology, Sophia Antipolis.

Nieman, B. J., \& Turnbull, D. H. (2010). Ultrasound and magnetic resonance microimaging of mouse development. Methods in Enzymology, 476, 379-400.

Oxford, E. M., Danko, C. G., Kornreich, B. G., Maass, K., Hemsley, S. A., Raskolnikov, D., Fox, P. R., Delmar, M., \& Moïse, N. S. (2011). Ultrastructural changes in cardiac myocytes from Boxer dogs with arrhythmogenic right ventricular cardiomyopathy. Joumal of Veterinary Cardiology, 13(2), 101-113.

Patterson, A. J., \& Zhang, L. (2010). Hypoxia and fetal heart development. Current Molecular Medicine, 10(7), 653-666.

Pires-Gomes, A. A. S., \& Pérez-Pomares, J. M. (2013). The epicardium and artery formation. Journal Development Biology, 1, 186-202.

Porter, G. A., Hom, J., Hoffman, D., Quintanilla, R., de Mesy Bentley, K., \& Sheu, S. S. (2011). Bioenergetics, mitochondria, and cardiac myocyte differentiation. Progress in Pediatric, 31(2), 75-81

Price, R. L., Chintanowonges, C., Shiraishi, I., Borg, T. K., \& Terracio, L. (1996). Local and regional variations in myofibrillar patterns in looping rat hearts. The Anatomical Record, 245(1), 83-93.

Ratajska, A., Ciszek, B., \& Sowińska, A. (2003). Embryonic development of coronary vasculature in rats: Corrosion casting studies. The Anatomical Record. Part A, Discoveries in Molecular, Cellular, and Evolutionary Biology, 270(2), 109-116.

Raxcheeva, M. V., \& Bugrova, M. L. (2010). Izmenenie sootnoshenija granul AB-tipov, soderzhashhih predserdnyj i mozgovoj natrijureticheskie peptidy, v predserdnyh miocitah krys $\mathrm{v}$ uslovijah vazorenal'noj gipertenzii [Change in correlation of A- and B-type granules containing atrial and brain natriuretic peptides in atrial rat myocytes under conditions of renovascular hypertension]. Citologija, 52(8), 629-633 (in Russian).

Ream, M., Ray, A. M., Chandra, R., \& Chikaraishi, D. M. (2008). Early fetal hypoxia leads to growth restriction and myocardial thinning. American Journal of Physiology. Regulatory, Integrative and Comparative Physiology, 295(2), 583-595.

Rook, W., Johnson, C. D., Coney, A. M., \& Marshall, J. M. (2014). Prenatal hypoxia leads to increased muscle sympathetic nerve activity, sympathetic hyperinnervation, premature blunting of neuropeptide $\mathrm{Y}$ signaling, and hypertension in adult life. Hypertension, 64(6), 1321-1327.

Ruckman, R. N., Rosenquist, G. C., Rademaker, D. A., Morse, D. E., \& Getson, P. R. (1985). The effect of graded hypoxia on the embryonic chick heart. Teratology, 32(3), 463-472.

Saiki, Y., Konig, A., Waddell, J., \& Rebeyka, I. M. (1997). Hemodynamic alteration by fetal surgery accelerates myocyte proliferation in fetal guinea pig hearts. Surgery, 122(2), 412-419.

Samsa, L. A., Yang, B., \& Liu, J. (2013). Embryonic cardiac chamber maturation: trabeculation, conduction, and cardiomyocyte proliferation. American Journal of Medical Genetics. Part C, Seminars in Medical Genetics, 163(3), 157-168.

Schaper, J., Meiser, E., \& Stämmler, G. (1985). Ultrastructural morphometric analysis of myocardium from dogs, rats, hamsters, mice, and from human hearts. Circulation Research, 56(3), 377-391.

Schell, M. T., Spitzer, A. L., Johnson, J. A., Lee, D., \& Harris, H. W. (2005). Heat shock inhibits NF-kB activation in a dose- and time-dependent manner. The Journal of Surgical Sesearch, 129(3), 90-93.

Schleich, J. M., Dillenseger, J. L., Loeuillet, L., Moulinoux, J. P., \& Almange, C. (2005). Three-dimensional reconstruction and morphologic measurements of human embryonic hearts: a new diagnostic and quantitative method applicable to fetuses younger than 13 weeks of gestation. Pediatric and Developmental Pathology, 8(4), 463-473.

Schotten, U., Verheule, S., Kirchhof, P., \& Goette, A. (2011). Pathophysiological mechanisms of atrial fibrillation: A translationalappraisal. Physiological Reviews, 91, 265-325.

Sergeeva, I. A., Hooijkaas, I. B., Van Der Made, I., Jong, W. M., Creemers, E. E., \& Christoffels, V. M. (2014). A transgenic mouse model for the simultaneous monitoring of ANF and BNP gene activity during heart development and disease. Cardiovascular Research, 101(1), 78-86.
Shatorna, V. F., Shponka, I. S., Abdul-Ohly, L. V., \& Savenkova, O. O. (2010). Krytychni periody kardiohenezu [Critical periods of cardiogenesis]. Porohy, Dnipropetrovsk (in Ukrainian).

Shevchenko, K. M., \& Tverdokhlib, I. V. (2012). Ontogenetychni osoblyvosti sekretornogo aparatu peredserdnogo miokarda shhuriv [Ontogenetic features of the secretory apparatus of the atrial myocardium in rats]. Morphology, 6(3), 72-77 (in Ukrainian)

Shponka, I. S. (1996). Gistogeneticheskie processy v razvivayushhemsya miokarde mlekopitayushhih [Histogenetic processes in the developing mammalian myocardium]. Porogi, Dnepropetrovsk (in Russian).

Silkina, Y. V. (2010). Gistogenetychni peretvorennja providnoi' systemy sercja [Histogenetic transformation of conducting system ofthe heart]. Morphology, 4(3), 50-66 (in Ukrainian)

Sugishita, Y., Leifer, D. W., Agani, F., Watanabe, M., \& Fisher, S. A. (2004). Hypoxia-responsive signaling regulates the apoptosis-dependent remodeling of the embryonic avian cardiac outflow tract. Developmental Biology, 273(2), 285-296.

Takei, Y., Inoue, K., Trajanovska, S., \& Donald, J. A. (2011). B-type natriuretic peptide (BNP), not ANP, is the principal cardiac natriuretic peptide in vertebrates as revealed by comparative studies. General and Comparative Endocrinology, 171, 258-266.

Tobón, C., Ruiz-Villa, C. A., Heidenreich, E., Romero, L, Hornero, F., \& Saiz, J. (2013). A three-dimensional human atrial model with fiber orientation. Electrograms and arrhythmic activation patterns relationship. PLoS One, 8(2), e50883.

Tomanek, R, J., \& Zheng, W. (2002). Role of growth factors incoronary morphogenesis. Texas Heart Institute Journal, 29(4), 250-254.

Tomanek, R. J., Haung, L., Suvarna, P. R., O'Brien, L. C., Ratajska, A., \& Sandra, A (1996). Coronary vascularization during development in the rat and its relationship to basic fibroblast growth. Cardiovascular Researches, 31, 116-126.

Tomanek, R. J., Ratajska, A., Kitten, G. T., Yue, X., \& Sandra, A. (1999). Vascular endothelial growth factor expression coincideswith coronary vasculogenesis and angiogenesis. Developmental Dynamics, 215(1), 54-61.

Tong, W., Xiong, F., Li, Y., \& Zhang, L. (2013). Hypoxia inhibits cardiomyocyte proliferation in fetal rat hearts via upregulating TIMP-4. American Journal of Physiology. Regulatory, Integrative and Comparative Physiology, 304(8), 613-620.

Tong, W., Xue, Q., Li, Y., \& Zhang, L. (2011). Maternal hypoxia alters matrix metalloproteinase expression patterns and causes cardiac remodeling in fetal and neonatal rats. American Journal of Physiology. Heart and Circulatory Physiology, 301(5), 2113-2121.

Tonne, J. M., Campbell, J. M., Cataliotti, A., Ohmine, S., Thatava, T., Sakuma, T., Macheret, F., Huntley, B. K., Burnett, J. C., \& Ikeda, Y. (2011). Secretion of glycosylated pro-B-type natriuretic peptide from normal cardiomyocytes. Clinical Chemistry, 57(6), 864-873.

Tverdokhlib, I. V. (2007). Prostorova rekonstrukcija biologichnyh objektiv za dopomogoju komp'juternogo modeljuvannja [Dimensional reconstruction of biological objects using computer modeling]. Morphology, 1(1), 135-139 (in Ukrainian).

Wilhide, M. E., Tranter, M., Ren, X., Chen, J., Sartor, M. A., Medvedovic, M., \& Jones, W. K. (2011). Identification of a NF- $\mathrm{kB}$ cardioprotective gene program: $\mathrm{NF}-\kappa \mathrm{B}$ regulation of Hsp70.1 contributes to cardioprotection after permanent coronary occlusion. Joumal of Molecular and Cellular Cardiology, 51(1), 82-89.

Writing Committee, Smith, S.C., Collins, A., Ferrari, R., Holmes, D. R., Logstrup, S., McGhie, D. V., Ralston, J., Sacco, R. L., Stam, H., Taubert, K., Wood, D. A., \& Zoghbi, W. A. (2012). Our time: A call to save preventable death from cardiovascular disease (heart disease and stroke). Global Heart, 60 2343-2348.

Yu, J., Zhu, M. Z., Cheng, B. Y., Lu, S. Y., \& Dong, M. Q. (2003). Study on the mechanism of how vasonatrin peptide can attenuate the growth-promoting effect of hypoxia in cardiac fibroblast. Zhongguo Ying Yong Sheng Li Xue Za Zhi i. Chinese Journal of Applied Physiology, 19(1), 8-11.

Yunge, L., Ballak, M., Beuzeron, J., Lacasse, J., \& Cantin, M. (1980). Ultrastructural cytochemistry of atrial and ventricular cardiocytes of the bullforg. Relationship of specific granules with reninlike activity of the myocardium. Canadian Joumal of Physiology and Pharmacology, 58, 1463-1476.

Zadnipryanyj, I. V., \& Tretyakova, O. S. (2011). Strukturnaja perestrojka miokarda pri perinatal'noj gipoksii $\mathrm{v}$ uslovijah jeksperimenta [Structural remodeling of myocardum during perinatal hypoxia under experimental conditions]. Crimean Journal of Experimental and Clinical Medicine, 1(1), 40-45 (in Russian).

Zhang, F., \& Pasumarthi, K. B. (2007). Ultrastructural and immunocharacterization of undifferentiated myocardial cells in the developing mouse heart. Journal of Cellular and Molecular Medicine, 11(3), 552-560.

Zhang, W., Chen, H., Qu, X., Chang, C. P., \& Shou, W. (2005). Myocardial heterogeneity in permissiveness for epicardium-derived cells and endothelial precursor cells along the developing heart tube at the onset of coronary vascularization. American Journal of Medical Genetics, 282(2), 120-129.

Zhang, W., Chen, H., Qu, X., Chang, C. P., \& Shou, W. (2013). Molecular mechanism of ventricular trabeculation/compaction and the pathogenesis of the left ventricular noncompaction cardiomyopathy (LVNC). American Journal of Medical Genetics. Part C, Seminars in Medical Genetics, 163(3), 144-156. 